J. Dairy Sci. 99:3367-3374

http://dx.doi.org/10.3168/jds.2015-10495

(C) American Dairy Science Association ${ }^{\circledR}, 2016$.

\title{
The effect of storage temperature and duration on the microbial quality of bulk tank milk
}

\author{
A. O’Connell, ${ }^{\star} †$ P. L. Ruegg,† K. Jordan, $\ddagger$ B. O’Brien, ${ }^{*}$ and D. Gleeson*1 \\ *Teagasc, Livestock Systems Research Department, Animal and Grassland Research and Innovation Centre, Moorepark, Fermoy, \\ Co. Cork, Ireland \\ †Department of Dairy Science, University of Wisconsin-Madison, Madison 53706 \\ $\ddagger$ Teagasc Food Safety Department, Food Research Centre, Moorepark, Fermoy, Co. Cork, Ireland
}

\begin{abstract}
The dairy industry in Ireland is currently undergoing a period of expansion and, as a result, it is anticipated that milk may be stored in bulk tanks on-farm for periods greater than $48 \mathrm{~h}$. The objective of this study was to investigate the effects of storage temperature and duration on microbial quality of bulk tank milk when fresh milk is added to the bulk tank twice daily. Bulk tank milk stored at 3 temperatures was sampled at 24-h intervals during storage periods of 0 to $96 \mathrm{~h}$. Bulk tank milk samples were analyzed for total bacterial count (TBC), psychrotrophic bacterial count (PBC), laboratory pasteurization count (LPC), psychrotrophicthermoduric bacterial count (PBC-LPC), proteolytic bacterial count, lipolytic bacterial count, presumptive Bacillus cereus, sulfite-reducing Clostridia (SRC), and SCC. The bulk tank milk temperature was set at each of 3 temperatures $\left(2^{\circ} \mathrm{C}, 4^{\circ} \mathrm{C}\right.$, and $\left.6^{\circ} \mathrm{C}\right)$ in each of 3 tanks on 2 occasions during two 6 -wk periods. Period 1 was undertaken in August and September, when all cows were in mid lactation, and period 2 was undertaken in October and November, when all cows were in late lactation. None of the bulk tank bacterial counts except the proteolytic count were affected by lactation period. The proteolytic bacterial count was greater in period 2 than in period 1. The TBC and PBC of milk stored at $6^{\circ} \mathrm{C}$ increased as storage duration increased. The TBC did not increase with increasing storage duration when milk was stored at $2^{\circ} \mathrm{C}$ or $4^{\circ} \mathrm{C}$ but the $\mathrm{PBC}$ of milk stored at $4^{\circ} \mathrm{C}$ increased significantly between 0 and 96 $\mathrm{h}$. The numbers of proteolytic and lipolytic bacteria, LPC, or PBC-LPC in bulk tank milk were not affected by temperature or duration of storage. Presumptive B. cereus were detected in $10 \%$ of all bulk tank milk
\end{abstract}

Received October 7, 2015.

Accepted December 10, 2015.

${ }^{1}$ Corresponding author: david.gleeson@teagasc.ie samples taken over the two 6-wk periods, with similar proportions observed in both. In bulk tank milk samples, a greater incidence of SRC was observed in period $2(20 \%)$ compared with period 1 (3\%). Milk produced on-farm with minimal bacterial contamination can be successfully stored at $2^{\circ} \mathrm{C}$ and $4^{\circ} \mathrm{C}$ for up to $96 \mathrm{~h}$ with little effect on its microbial quality.

Key words: raw milk, milk storage, storage temperature, total bacteria count, psychrotrophic bacteria

\section{INTRODUCTION}

The abolition of the European Union milk quota system in April 2015 will likely lead to a significant increase in milk production within the Irish dairy sector, and the national strategy anticipates an expansion of $50 \%$ by 2020 (DAFM, 2010). Because approximately $85 \%$ of milk produced in Ireland is exported as dairy products, further expansion in milk production will necessitate expansion of the dairy export market. However, the success of this expansion is reliant on the production of high quality milk to produce a wide range of top quality products (O'Brien et al., 2009).

Because of expansion, it is likely that bulk tank milk storage time will be extended on farms. European Union legislation specifies that milk produced and stored on-farm must be cooled to at least $8^{\circ} \mathrm{C}$ (when collected daily). In Ireland, milk is usually collected at 48-h intervals, but in spring and winter, the collection interval is often extended to $96 \mathrm{~h}$. Milk processors request that milk be cooled to 2 to $4^{\circ} \mathrm{C}$ within 2 to $3 \mathrm{~h}$ of milking. Milk cooling has the largest electrical energy consumption on Irish dairy farms (Upton et al., 2013). Thus, there may be an economic incentive for farmers to cool and store milk at higher temperatures (e.g., at $6^{\circ} \mathrm{C}$ compared with $2^{\circ} \mathrm{C}$ ), especially if milk is being stored for an extended duration.

Microbial tests such as the total bacteria count (TBC) and psychrotrophic bacterial count (PBC) are 
used to characterize raw milk quality and have been demonstrated to be affected by storage time and temperature. A study by Muir et al. (1978) showed that when milk was stored at $4^{\circ} \mathrm{C}, 6^{\circ} \mathrm{C}$, and $8^{\circ} \mathrm{C}$, the $\mathrm{TBC}$ increased from a starting value of $3.2 \times 10^{3} \mathrm{cfu} / \mathrm{mL}$, to $5.2 \times 10^{5}$ at $4^{\circ} \mathrm{C}, 3.3 \times 10^{6}$ at $6^{\circ} \mathrm{C}$, and $1.0 \times 10^{7}$ at $8^{\circ} \mathrm{C}$, after $105 \mathrm{~h}$ of storage. Meanwhile, psychrotrophic bacterial growth remained in the lag phase for at least part of the first 48-h period when milk was stored at $4^{\circ} \mathrm{C}$ and $6^{\circ} \mathrm{C}$, whereas immediate growth was observed in milk stored at $8^{\circ} \mathrm{C}$. A further study by Griffiths et al. (1987) showed that the time taken for the PBC in milk to increase from $2.6 \times 10^{2}$ to $>10^{6} \mathrm{cfu} / \mathrm{mL}$ was 2.9 and $5.0 \mathrm{~d}$ when milk was stored at $6^{\circ} \mathrm{C}$ and $2^{\circ} \mathrm{C}$, respectively.

Spoilage bacteria such as proteolytic and lipolytic bacteria can also grow in milk during storage (Celestino et al., 1996) and alter the quality and shelf life of the milk. Such bacteria are capable of producing proteases and lipases that can break down milk protein and fat, leading to casein damage and the development of rancid and bitter flavors (Muir, 1996).

Laboratory pasteurization count (LPC) as well as thermoduric and psychrotrophic-thermoduric (PBCLPC) bacteria can survive pasteurization and multiply during processing and can contribute to milk spoilage (Fromm and Boor, 2004). Two bacterial groups that are capable of surviving pasteurization and that can cause illness when ingested in large numbers are Bacillus cereus (aerobic spore-formers) and sulfite-reducing Clostridia (SRC; anaerobic spore-formers). The numbers of B. cereus and SRC present in milk are closely monitored during the manufacture of infant milk formula due to the possibility of toxin production and the vulnerability of its consumers. Thus, limiting the exposure of raw milk to contamination with $B$. cereus and SRC at the farm level is necessary.

Although previous studies have investigated microbial growth in milk during storage, those studies have been laboratory-based (Griffiths et al., 1987; Wiking et al., 2002; Malcarne et al., 2013) and may not entirely reflect on-farm conditions. The on-farm scenario involves the addition of warm fresh milk at each milking, which is blended with the cooled milk present in the bulk tank. The effect of storage conditions on the microbial quality of such blended milk has yet to be investigated and is likely to be more representative of what occurs on commercial farms than previous laboratory-based experiments.

The objective of this study was to investigate the effects of milk storage temperature and storage time on the microbial quality of bulk tank milk when fresh milk was added twice daily throughout the storage period.

\section{MATERIALS AND METHODS}

\section{Experimental Design}

The experiment was conducted at the Animal and Grassland Research and Innovation Centre, Teagasc, Moorepark, Cork, Ireland, using milk produced from spring-calving dairy cows. Milk production over two 6-wk periods was studied; period 1 extended from August 11 to September 26, and period 2 extended from October 13 to November 21. During period 1 and the first 4 wk of period 2, the cows were outdoors consuming a diet of grass. During the remaining 2 wk of period 2 , the cows were partially housed indoors during times of heavy rainfall on cubicles fitted with rubber mats that were bedded with lime, and they consumed a diet consisting of approximately $50 \%$ grazed grass and $50 \%$ grass silage. Milk was harvested on 48 occasions during each period. At each milking, before cluster attachment, teats were disinfected with polymoric biguanide hydrochloride (Super Cow Teat Foam, Milk Solutions Ltd., Kilworth, Co. Cork, Ireland) and dried using individual paper towels. Cows were milked twice a day at 10- and 14-h intervals in a 30-unit side-by-side milking parlor. The milk was transferred from the cluster to the midlevel milk-line (72 mm, internal diameter) in 16-mm (internal diameter) milk tubes, with a milk lift of 1.5 $\mathrm{m}$, and from there to the receiver jar. The clusters were automatically removed as directed by the electronic milk meters when the milk flow rate decreased to 0.2 $\mathrm{kg} / \mathrm{min}$ with a delay time of $20 \mathrm{~s}$.

The milk was pumped from the receiver jar through a 48-mm stainless steel pipe, under laminar flow conditions using a variable speed milk pump. After each milking occasion, the milking equipment was rinsed with water $(14 \mathrm{~L} /$ milking unit). This was followed by a hot $\left(65\right.$ to $\left.75^{\circ} \mathrm{C}\right)$ liquid detergent sterilizer (Liquid Gold, Dairymaster, Causeway, Kerry, Ireland) wash (9 $\mathrm{L} / \mathrm{unit}$ ) that was left to circulate for 8 to $10 \mathrm{~min}$. Immediately after the detergent sterilizer wash, the milking equipment was rinsed twice, with the final rinse containing peracetic acid (0.3-0.5\%). Once a week, an acid-descale (Extra-Strong Descaler, Dairymaster) washing cycle was incorporated into the milking regimen before the detergent cycle.

Three identical bulk milk tanks with a capacity of $4,000 \mathrm{~L}$ (Swiftcool, Dairymaster) were used in this study. Each tank was fitted with a 5.5-Hp condensing unit and a single-stage plate cooler (37 plates). Data on milk temperature, desired milk temperature setting, time of day, and milk volume in the tank were displayed on each tank. Each tank was set at each of the 3 temperatures $\left(2^{\circ} \mathrm{C}, 4^{\circ} \mathrm{C}\right.$, and $\left.6^{\circ} \mathrm{C}\right)$ on 2 occasions 
during each 6 -wk period, resulting in 6 test periods $(2$ at each temperature) during which milk was stored for up to $96 \mathrm{~h}$, for each test period. The 3 bulk tanks were set to cool milk to the different temperatures at the beginning of each test period. Valves in the milk-line were used to divide the milk flow in equal proportions to each of the 3 tanks. The milk passed through a plate cooler and was cooled to approximately $14.5^{\circ} \mathrm{C}$ before entering each tank. The milk was subsequently cooled to the desired temperature within the tank.

Immediately after the bulk tanks were emptied after each 96-h storage period, the tanks were washed using a regimen incorporating a cold water rinse followed by a hot $\left(50^{\circ} \mathrm{C}\right)$ detergent/sterilizer wash, followed by 2 additional rinses, with the final rinse containing peracetic acid. At every third wash, the detergent/sterilizer cleaning product was replaced with an acid wash product.

\section{Milk Sampling}

Duplicate bulk tank milk samples $(50 \mathrm{~mL})$ were taken from each tank immediately after the initial morning milking once milk was cooled to the desired temperature and subsequently at $24,48,72$, and $96 \mathrm{~h}$, before morning milking, when there was milk from $2,4,6$, and 8 milkings, respectively, in each tank. Before sample collection, the milk was agitated at $24 \mathrm{rpm}$ for $10 \mathrm{~min}$. Samples were collected through the viewing inlet on the top of each tank using a sanitized milk sample dipper $(50 \mathrm{~mL})$, in accordance with the procedure outlined by Graham (2004). The temperature and the volume of milk displayed on each tank were manually recorded. The milk samples were stored on ice during transport to the laboratory and delivered within $30 \mathrm{~min}$ of sample collection. Samples were stored at $4^{\circ} \mathrm{C}$ in the laboratory until analysis later on the same day.

To assess the quality of milk entering the bulk tanks, a milk sample was taken from the milk-line, before the milk was diverted into each of the 3 tanks. A sample tap fitted to the milk-line, which recovered a constant stream of milk throughout milking, was used to collect this sample. The milk was collected in a sterile Durham flask that was surrounded by ice.

\section{Microbiological and SCC Analyses}

Duplicate samples collected from the milk-line were analyzed for TBC immediately after delivery to the laboratory, whereas the LPC and SCC were measured within $24 \mathrm{~h}$. Duplicate milk samples from each tank were analyzed for TBC, LPC, PBC, PBC-LPC, proteolytic count, lipolytic count, and for the presence of presumptive B. cereus and SRC. The TBC, LPC, PBC, and PBC-LPC were measured using Petrifilm (3M, Technopath, Tipperary, Ireland) in accordance with procedures outlined by Laird et al. (2004). All LPC and PBC-LPC samples were pasteurized at $63^{\circ} \mathrm{C}$ for $30 \mathrm{~min}$ before plating (Frank and Yousef, 2004). The TBC and $\mathrm{LPC}$ samples were incubated for $48 \mathrm{~h}$ at $32^{\circ} \mathrm{C}$ (Laird et al., 2004), whereas PBC and PBC-LPC samples were incubated for $10 \mathrm{~d}$ at $7^{\circ} \mathrm{C}$ (Frank and Yousef, 2004). Petrifilm plates were read electronically using the Petrifilm Plate Reader (3M, Technopath). The SCC of each sample was measured using a Fossomatic FC (Foss Electric, Hillerød, Denmark).

To determine the number of lipolytic bacteria in milk samples, $100 \mu \mathrm{L}$ of milk was plated on tributyrin agar (Sigma Aldrich, Dublin, Ireland) and incubated at $37^{\circ} \mathrm{C}$ for $48 \mathrm{~h}$. Lipolytic colonies were identified as colonies surrounded by a clear zone in an otherwise turbid culture medium. To determine the number of proteolytic bacteria in milk, $100 \mu \mathrm{L}$ was plated on calcium caseinate agar (Merck, Darmstadt, Germany) and incubated at $37^{\circ} \mathrm{C}$ for $48 \mathrm{~h}$. Proteolytic colonies were identified as colonies surrounded by a clear zone in an otherwise opaque medium. To determine the number of presumptive $B$. cereus in the milk samples, $100 \mu \mathrm{L}$ was spread on Bacara agar plates (bioMerieux, Basingstoke, UK), which were incubated at $32^{\circ} \mathrm{C}$ for $24 \mathrm{~h}$. Presumptive $B$. cereus colonies were identified as pink-orange colonies surrounded by an opaque halo (Tallent et al., 2012). The presumptive number of SRC in the milk samples was determined in accordance with the ISO standard 15213 (ISO, 2003). Briefly, $1 \mathrm{~mL}$ of each milk sample was pour-plated in iron sulfite agar and incubated under anaerobic conditions for $72 \mathrm{~h}$ at $37^{\circ} \mathrm{C}$. Black colonies were counted as presumptive SRC.

\section{Statistical Analysis}

The study was conducted using a multiple Latin square design with repeated measures (sampling BTM every $24 \mathrm{~h}$ ) whereby each temperature $\left(2,4\right.$, and $\left.6^{\circ} \mathrm{C}\right)$ and each bulk tank $(\mathrm{n}=3)$ were present in each week $(\mathrm{n}=6)$ for each lactation period $(\mathrm{n}=2)$. Each Latin square was repeated 4 times throughout the study. Least squares means for the main effects of storage time, temperature, and lactation stage, and their interaction were calculated using the MIXED procedure in SAS 9.3 (SAS Institute, 2011). Storage time was defined as the total number of hours each tank had been cooling since the first addition of milk. Tank within week was the experimental unit. Response variables were TBC, PBC, proteolytic count, and lipolytic count. The fixed effects included in each model were lactation period (1 or 2 ), week ( 1 to 12$)$, tank ( 1 to 3 ), time (0, 24, 48, 
Table 1. Unadjusted means and distribution of $\log _{10}$ total bacterial count (TBC), $\log _{10}$ laboratory pasteurization count (LPC), and log 10 SCC of milk sampled at each milking in lactation periods 1 and 2 from the milk-line before being distributed to each tank

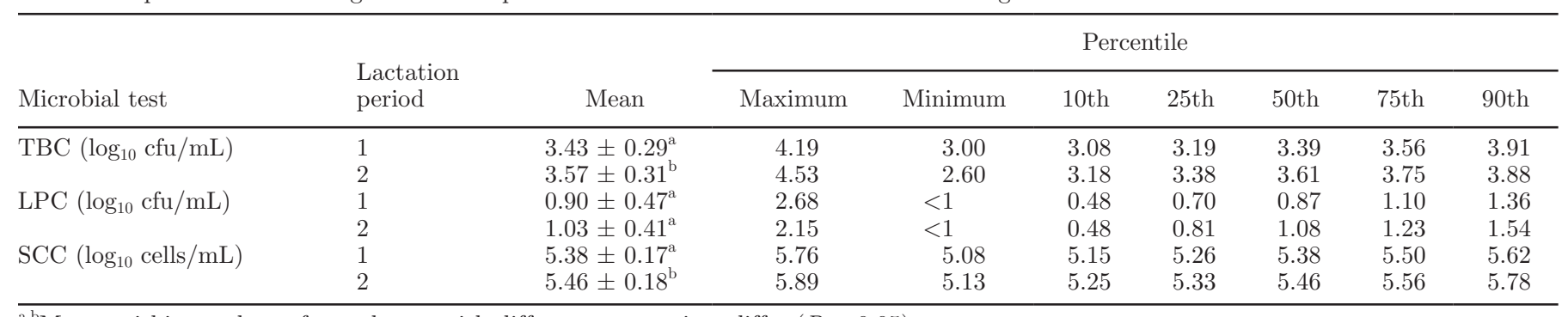

${ }^{\mathrm{a}, \mathrm{b}}$ Means within a column for each test with different superscripts differ $(P<0.05)$.

72 , and $96 \mathrm{~h})$, and temperature $\left(2,4\right.$, and $\left.6^{\circ} \mathrm{C}\right)$. The 2 -way interaction between time and temperature and the 3-way interaction between time, temperature, and lactation period were included in each model. When lactation period and the interaction between time, temperature, and lactation period were not significant in a model, they were subsequently removed. Storage time was included in the REPEATED statement of the procedure. The unstructured covariance structure was used in all models. Residual checks were made to ensure that the assumptions of the analysis model were met, and $\log _{10}$ transformation was used to correct positive skew and nonconstant variance for all responses. Treatment means were compared using the Tukey test at $5 \%$ error probability. Correlations among microbial parameters (using $\log _{10}$-transformed values) were assessed using the Pearson correlation coefficient with PROC CORR (SAS Institute, 2011). The prevalence of presumptive positive $B$. cereus and SRC isolates in each lactation period was calculated as the number of positive samples divided by the total number of samples for that lactation stage and compared as 2 independent binomial samples. Because of the lack of variation between the results for LPC and PBCLPC, no formal statistical analysis was carried out, as analysis may confer statistical significance that has no biological relevance. Instead, unadjusted means for LPC and PBC-LPC are presented.

The results are presented as the $\log _{10}$-transformed values with back-transformed values in parentheses.

\section{RESULTS}

\section{Milk Supply}

The unadjusted mean TBC entering the tanks was greater in period $2(3,715 \mathrm{cfu} / \mathrm{mL})$ than period $1(2,691$ $\mathrm{cfu} / \mathrm{mL}$; Table $1, P=0.03)$. Similarly, the mean SCC of milk entering the tanks was greater in period $2(288,403$ $\mathrm{cfu} / \mathrm{mL})$ than in period $1(239,883 \mathrm{cfu} / \mathrm{mL}$; Table $1, P$ $=0.03)$. Across both periods, the LPC of milk entering the bulk tanks ranged from $<1$ to $2.68 \mathrm{log} \mathrm{cfu} / \mathrm{mL}$ but the unadjusted mean values for each period were not different (Table 1, $P=0.18$ ).

\section{Effect of Lactation Period on Storage Conditions}

Neither the main effect of lactation period $(P=0.19)$ nor the interaction between lactation period, temperature, and storage time $(P=0.29)$ had a significant effect on the $\log _{10}$ TBC. Trends of PBC and lipolytic count in milk stored at different temperatures between 0 and $96 \mathrm{~h}$ were similar in period 1 and period 2 . Neither lactation period $(P=0.17)$ nor the 3 -way interaction had a significant effect $(P=0.59)$ on $\log _{10}$ PBC. Similarly, neither lactation period $(P=0.97)$ nor the 3 -way interaction had a significant effect $(P=0.91)$ on the $\log _{10}$ lipolytic count. Therefore, the results for TBC, PBC, and lipolytic count represent the total 12 wk of sampling.

The mean proteolytic bacterial count for period 1 $(858 \mathrm{cfu} / \mathrm{mL})$ was less than that for period $2(1,037$ $\mathrm{cfu} / \mathrm{mL} ; P=0.002)$. More importantly, the interaction for proteolytic bacteria between lactation period, storage temperature, and storage time was not significant $(P=0.15)$. Consequently, the results for the proteolytic bacterial count represent the total 12 wk of sampling.

\section{TBC}

The $\log _{10}$ TBC in bulk tank milk was affected by storage time $(P<0.001)$, temperature $(P<0.001)$, and the interaction between storage time and temperature $\left(P<0.001\right.$; Table 2). When milk was stored at $6^{\circ} \mathrm{C}$, the $\log _{10}$ TBC increased from $3.43 \log _{10} \mathrm{cfu} / \mathrm{mL}(2,692 \mathrm{cfu} /$ $\mathrm{mL})$ to $4.87 \log _{10} \mathrm{cfu} / \mathrm{mL}(74,131 \mathrm{cfu} / \mathrm{mL})$ between 0 and $96 \mathrm{~h}(P<0.001)$. When milk was stored at $2^{\circ} \mathrm{C}$, there was no difference in $\log _{10}$ TBC between $0(2,399$ $\mathrm{cfu} / \mathrm{mL})$ and $96 \mathrm{~h}(3,388 \mathrm{cfu} / \mathrm{mL} ; P=0.99)$. Likewise, there was no difference in $\log _{10}$ TBC of milk stored at $4^{\circ} \mathrm{C}$ between $0(2,512 \mathrm{cfu} / \mathrm{mL})$ and $96 \mathrm{~h}(4,786 \mathrm{cfu} / \mathrm{mL}$; $P=0.99)$. 
Table 2. Least squares means of $\log _{10}$ total bacterial count (TBC), $\log _{10}$ psychrotrophic bacterial count (PBC), $\log _{10}$ proteolytic count, and $\log _{10}$ lipolytic count in blended bulk tank milk stored at different temperatures and for different durations

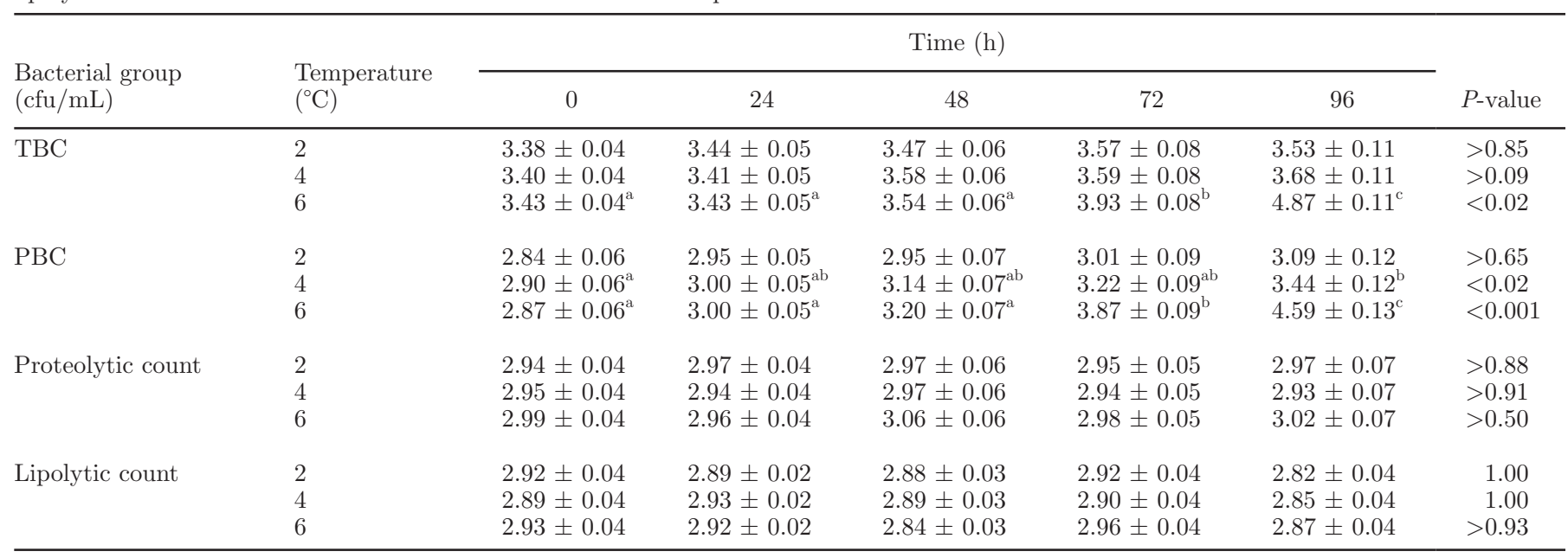

${ }^{a-c}$ Means within a row with different superscripts differ significantly.

\section{PBC}

The $\log _{10}$ PBC of bulk tank milk was affected by storage time $(P<0.001)$, storage temperature $(P<$ $0.001)$, and the interaction between storage time and temperature $(P<0.001$; Table 2$)$. When milk was stored at $4^{\circ} \mathrm{C}$, the $\log _{10} \mathrm{PBC}$ of the milk increased $(P$ $=0.016)$ between $0 \mathrm{~h}(794 \mathrm{cfu} / \mathrm{mL})$ and $96 \mathrm{~h}(2,754$ $\mathrm{cfu} / \mathrm{mL})$. When milk was stored at $6^{\circ} \mathrm{C}$, the $\log _{10} \mathrm{PBC}$ increased $(P<0.001)$ from $2.87 \log _{10} \mathrm{cfu} / \mathrm{mL}(741 \mathrm{cfu} /$ $\mathrm{mL})$ to $4.59 \mathrm{cfu} / \mathrm{mL}(38,904 \mathrm{cfu} / \mathrm{mL})$ between 0 and $96 \mathrm{~h}$. The $\log _{10} \mathrm{PBC}$ did not change between 0 and 48 $\mathrm{h}$ but was greater at $72 \mathrm{~h}(P<0.001)$ and $96 \mathrm{~h}(P<$ 0.001; Table 2).

The $\log _{10}$ TBC was correlated $(P<0.001)$ with $\log _{10}$ $\mathrm{PBC}$ at all temperatures. The correlation increased as temperature increased from $2^{\circ} \mathrm{C}(0.49)$ to $4^{\circ} \mathrm{C}(0.73)$ and $6^{\circ} \mathrm{C}(0.87$; Table 3$)$.

Table 3. Pearson correlation coefficients between $\log _{10}$ total bacterial count (TBC), $\log _{10}$ laboratory pasteurization count (LPC), $\log _{10}$ psychrotrophic bacteria count (PBC), $\log _{10}$ proteolytic count, $\log _{10}$ lipolytic count, and $\log _{10} \mathrm{SCC}$ of milk stored at different temperatures $\left(2^{\circ} \mathrm{C}, 4^{\circ} \mathrm{C}\right.$, and $\left.6^{\circ} \mathrm{C}\right)$

\begin{tabular}{|c|c|c|c|}
\hline Parameter & $2^{\circ} \mathrm{C}$ & $4^{\circ} \mathrm{C}$ & $6^{\circ} \mathrm{C}$ \\
\hline & \multicolumn{3}{|c|}{$\log \mathrm{TBC}$} \\
\hline $\log _{10} \mathrm{LPC}$ & 0.16 & -0.07 & 0.09 \\
\hline $\log _{10}$ PBC & $0.49^{* *}$ & $0.73^{* *}$ & $0.87^{* *}$ \\
\hline $\log _{10}$ SCC & 0.10 & 0.22 & 0.23 \\
\hline Log PBC & 0.13 & Log LPC & 0.01 \\
\hline & \multicolumn{3}{|c|}{ Log Proteolytic count } \\
\hline Log lipolytic count & $0.28^{*}$ & $0.46^{* *}$ & 0.17 \\
\hline
\end{tabular}

${ }^{*} P<0.05 ;{ }^{* *} P<0.01$.

\section{Proteolytic Count}

The $\log _{10}$ proteolytic count of bulk tank milk was not affected by storage time $(P=0.67)$ or temperature $(P$ $=0.17)$. Least squares means at all temperatures and times for the proteolytic count ranged from $2.94 \log _{10}$ $\mathrm{cfu} / \mathrm{mL}(873 \mathrm{cfu} / \mathrm{mL})$ to $3.06 \log _{10} \mathrm{cfu} / \mathrm{mL}(1,143 \mathrm{cfu} /$ $\mathrm{mL}$; Table 2).

\section{Lipolytic Count}

The $\log _{10}$ lipolytic count was not affected by storage temperature $(P=0.59)$ but was affected by storage time $(P<0.01)$. The lipolytic count ranged from 2.91 $\log _{10} \mathrm{cfu} / \mathrm{mL}(812 \mathrm{cfu} / \mathrm{mL})$ to $2.85 \log _{10} \mathrm{cfu} / \mathrm{mL}(707$ $\mathrm{cfu} / \mathrm{mL}$ ) between 0 and $96 \mathrm{~h}$. The interaction between storage temperature and time had no effect $(P=0.70)$ on the $\log _{10}$ lipolytic count (Table 2).

\section{$L P C$ and $P B C-L P C$}

The LPC of all milk samples obtained from the bulk tanks ranged between 2 and $49 \mathrm{cfu} / \mathrm{mL}$, with $75 \%$ of samples having an LPC $<18 \mathrm{cfu} / \mathrm{mL}$ (data not shown). Due to the lack of variation among bulk tank milk samples and the low counts observed for LPC and PBC-LPC, no statistical analysis was performed to investigate the effect of storage time and temperature on the LPC and PBC-LPC. Instead, the unadjusted means for LPC and PBC-LPC were calculated by time period and storage temperature. The unadjusted means for all storage conditions for LPC and LPC-PBC ranged from 0.94 to $1.20 \log _{10} \mathrm{cfu} / \mathrm{mL}$ (9 to $16 \mathrm{cfu} / \mathrm{mL}$ ) and from 0.25 to $0.48 \log _{10} \mathrm{cfu} / \mathrm{mL}$ (2 to $6 \mathrm{cfu} / \mathrm{mL}$ ), respectively. 


\section{B. cereus and SRC}

Presumptive $B$. cereus colonies were not detected in $90 \%$ of milk samples (detection limit of $10 \mathrm{cfu} / \mathrm{mL}$ ). At least one colony of presumptive $B$. cereus was isolated from $8 \%$ of all samples in period 1 and from $12 \%$ of all samples in period 2; however, this difference was not significant.

At least one colony of presumptive SRC was isolated from $12 \%$ of all bulk tank samples. We detected a significant effect of stage of lactation $(P<0.001)$, whereby $20 \%$ of samples were positive for SRC in period 2 , whereas only $3 \%$ were positive for SRC in period 1 .

\section{DISCUSSION}

Although the sample size was modest $(\mathrm{n}=48$ for each period), the variation in TBC of milk entering the tanks was small and thus a significant difference was found in the mean TBC for each lactation period. However, this difference in mean TBC for each period was approximately $1,000 \mathrm{cfu} / \mathrm{mL}$ and was not considered biologically relevant. When milk was stored, this difference was not detected, as evident from the lack of significance for the interaction between lactation period, storage temperature, and storage duration in the multivariate models for each of the bacterial counts. This allowed us to combine the results from the two 6 -wk lactation periods for analysis; thus, all microbial results represent the total 12 wk of sampling.

There was no increase in the TBC of bulk tank milk stored at $2^{\circ} \mathrm{C}$ and $4^{\circ} \mathrm{C}$ for up to $96 \mathrm{~h}$. The European Union imposes a regulatory limit on bulk tank milk of $<100,000 \mathrm{TBC} \mathrm{cfu} / \mathrm{mL}$ (geometric average over a period of 2 mo, with at least 2 samples a month; European Economic Community, 1992), whereas some Irish milk processors impose a more stringent limit of 30,000 $\mathrm{cfu} / \mathrm{mL}$ on bulk tank milk. When milk was stored at $6^{\circ} \mathrm{C}$, significant bacterial growth was observed in milk for periods greater than $48 \mathrm{~h}$ and reached regulatory thresholds when stored for $96 \mathrm{~h}$. This deterioration in milk quality occurred at $6^{\circ} \mathrm{C}$ even though the initial quality of $75 \%$ of samples was $\leq 4,800 \mathrm{cfu} / \mathrm{mL}$. The results of this study indicate that when the initial TBC of milk was low and milk was stored at temperatures $\leq 4^{\circ} \mathrm{C}$, bacterial quantities were maintained at acceptable numbers for up to $96 \mathrm{~h}$. Similarly, Wiking et al. (2002) reported that, in a laboratory experiment, from a starting value of $3,500 \mathrm{cfu} / \mathrm{mL}$, total bacterial growth was inhibited in milk stored at $4^{\circ} \mathrm{C}$ but increased rapidly in milk stored at $8^{\circ} \mathrm{C}$ from $48 \mathrm{~h}$ onward, and approached $1 \times 10^{5} \mathrm{cfu} / \mathrm{mL}$ after $72 \mathrm{~h}$. As the initial microbial load of the milk has a marked effect on the length of time that milk can be stored (Guinot-Thomas et al., 1995), it is important to emphasize to farmers the importance of maintaining clean milking equipment and good hygiene during milking to minimize bacterial contamination of milk entering the bulk tank milk.

When milk was stored at $6^{\circ} \mathrm{C}$, we observed a rapid increase in $\log _{10}$ TBC for storage times greater than 48 $\mathrm{h}$, which was probably due to growth and dominance of psychrotrophic bacteria (Barbano et al., 2006). The strong correlation between $\log _{10} \mathrm{TBC}$ and $\log _{10} \mathrm{PBC}$ (at $4^{\circ} \mathrm{C}$ and $6^{\circ} \mathrm{C}$ ) supports this hypothesis. Significant growth of psychrotrophs was observed when milk was stored at $6^{\circ} \mathrm{C}$, whereas little or no growth was observed in milk stored at $2^{\circ} \mathrm{C}$ and $4^{\circ} \mathrm{C}$. Similar trends in growth of psychrotrophic bacteria in milk stored at different temperatures was observed by Griffiths et al. (1987), despite the fact that the initial psychrotrophic counts in that study (initial mean psychrotrophic count was $2,600 \mathrm{cfu} / \mathrm{mL}$ ) were much greater than that in the current study $(741 \mathrm{cfu} / \mathrm{mL})$. Likewise, Rasolofo et al. (2010) reported considerable growth of psychrotrophic bacteria in silo milk after $72 \mathrm{~h}$ of storage at $4^{\circ} \mathrm{C}$ and immediate growth when milk was stored at $8^{\circ} \mathrm{C}$. In our study, the psychrotrophic count of milked stored at $4^{\circ} \mathrm{C}$ was significantly greater at $96 \mathrm{~h}$ than at $0 \mathrm{~h}$; however, the psychrotrophic counts at 24,48 , and $72 \mathrm{~h}$ were similar to that at 0 and $96 \mathrm{~h}$. The limited increase in PBC at $4^{\circ} \mathrm{C}$ was probably due to the addition of high-quality fresh milk throughout the sampling period. Due to the addition of milk throughout storage, only milk from the first milking was stored for the full $96 \mathrm{~h}$. Thus, our study suggests that bulk tank milk with frequent additions of fresh milk with minimal bacterial contamination can be stored for up to $96 \mathrm{~h}$ at temperatures $\leq 4^{\circ} \mathrm{C}$ without considerable increases in psychrotrophic bacteria.

Although milk of poor bacteriological quality will deteriorate faster than milk with minimal contamination (Guinot-Thomas et al., 1995), the initial microbial load of raw milk cannot be used to accurately predict the bacterial quality of milk after refrigerated storage (Chambers, 2002). At any fixed temperature, there are often large differences in the growth rate of the various bacteria in raw milk, related to the predominant strains present in individual milk samples (Muir, 1996). At refrigeration temperatures between $6^{\circ} \mathrm{C}$ and $8^{\circ} \mathrm{C}$, differences in generation times of psychrotrophs can vary from $4 \mathrm{~h}$ to more than $12 \mathrm{~h}$ (Moatsou and Moschopoulou, 2014). In agreement, the variation between samples for $\mathrm{TBC}$ and $\mathrm{PBC}$ in the present study increased as storage time increased. Though initial counts were similar, the final counts varied widely.

The results of this study are not completely comparable to previous studies (Griffiths et al., 1987; Banks et al., 1988; Wiking et al., 2002) because our design 
included the addition of fresh milk at each milking throughout the storage period. In spite of this difference, similar trends were observed and significant growth of psychrotrophic bacteria and total bacteria after $48 \mathrm{~h}$ at temperatures $>4^{\circ} \mathrm{C}$ was reported in all studies. However, there are differences in mean bacterial counts among studies. Previous studies reported mean bacterial counts that exceeded $1 \times 10^{6} \mathrm{cfu} / \mathrm{mL}$ during storage at various temperatures (Banks et al., 1988; Griffiths et al., 1988). We observed few mean bacterial counts that exceeded 100,000 cfu/mL. Dilution as a result of addition of partially cooled $\left(14.5^{\circ} \mathrm{C}\right)$, high-quality fresh milk at each milking may account for the lower numbers of bacteria that we observed. After reporting changes in composition and bacterial counts of individual cow milk samples after storage for $48 \mathrm{~h}$ at $4^{\circ} \mathrm{C}$, Forsbäck et al. (2011) argued that milk leaving commercial farms every $48 \mathrm{~h}$ may already have deteriorated in quality. However, the authors of that laboratory-based study did not consider the addition of fresh milk throughout storage, which likely limits the rate of deterioration in milk quality. The design of this present study more closely mimics actual farm storage conditions.

The action of enzymes produced by bacteria during cold storage can cause lipolysis and proteolysis in milk. Celestino et al. (1996) reported that the number of proteolytic bacteria in milk significantly increased during storage from an average of 600 to $3,600 \mathrm{cfu} / \mathrm{mL}$. In the same study, the number of lipolytic bacteria in milk significantly increased from 8,000 to $19,000 \mathrm{cfu} / \mathrm{ml}(P<$ 0.01). In contrast to findings by Celestino et al. (1996), significant growth of lipolytic or proteolytic bacteria was not observed for any of the storage conditions that were tested in the current study. In Celestino et al. (1996), milk was sampled at a processing facility from a silo that contained milk produced on numerous farms. Thus, that milk had already been previously stored on farm for $48 \mathrm{~h}$, which may account for some differences in bacterial counts observed. Bacteria in milk can be in the exponential growth phase when milk reaches the processing facility and, therefore, milk in silos can be more susceptible to spoilage than when on the farm (Muir, 1996).

The low LPC and PBC-LPC in our milk samples were similar to findings of Celestino et al. (1996), who also recorded a low prevalence of psychrotrophic sporeformers in milk before and after storage at $4^{\circ} \mathrm{C}$ for 48 h. Griffiths et al. (1988) also found that the LPC of milk stored at $2^{\circ} \mathrm{C}$ did not increase during $72 \mathrm{~h}$ of storage. The findings from the current study and others (Griffiths et al., 1988; Celestino et al., 1996) suggest that thermoduric bacteria do not multiply during refrigerated storage and their presence in bulk tank milk is most likely due to contamination from the environment and milking equipment.

Milk produced with minimal contamination with $B$. cereus and SRC is desirable for infant milk formula production. Though $B$. cereus group members (in particular Bacillus weihenstephanensis) are capable of growing at temperatures $<6^{\circ} \mathrm{C}$ (Muir, 1996), the incidence of presumptive $B$. cereus was minimal in bulk tank milk in this study. Thus, it is likely that the milk entering the tank was not contaminated with presumptive $B$. cereus and as a result, the effect of storage conditions on the presumptive $B$. cereus count could not be measured. The minimal numbers of presumptive $B$. cereus measured may be a consequence of the strict milking and equipment hygiene implemented on this research farm. In this study, teats were thoroughly cleaned before unit attachment. However, this practice is not carried out on the majority of Irish dairy farms (Kelly et al., 2009). Thus, on commercial farms, the incidence of $B$. cereus in milk may be greater, particularly when cows are kept indoors (O'Connell et al., 2013). During period 2, the incidence of presumptive SRC in bulk tank milk increased compared with that in period 1 . This was probably due to the cows being housed indoors on cubicles for several hours per day and offered silage for the last 2 wk of period 2. Used bedding material (Magnusson et al., 2007) and contaminated silage (Vissers et al., 2007) are frequent sources of spore-forming bacteria and can contaminate teats. More stringent control practices may be necessary to combat the greater risk of contamination of milk with presumptive SRC at this time of the year due to deteriorating weather conditions and increased consumption of potentially contaminated silage (Aureli and Franciosa, 2002). Due to the low incidence of samples that were positive for $B$. cereus group bacteria and SRC, it was not possible to establish whether the numbers of these pathogens in milk was influenced by storage conditions. However, with good hygiene practices at milking and efficient equipment sanitation, milk production with minimal contamination with these pathogens is achievable.

\section{CONCLUSIONS}

Few, if any, researchers have examined the effect of storage conditions on milk stored in bulk tanks located on farms. Such studies are a better reflection of conditions experienced on commercial farms. In this study, milk entering the tank was of high microbial quality, which may be a critical factor influencing the results. The bacterial counts observed were considerably less than those reported in other studies, which is likely due to the frequent addition of fresh milk to the bulk tanks throughout storage. This study suggests that bulk tank 
milk can be stored at $2^{\circ} \mathrm{C}$ or $4^{\circ} \mathrm{C}$ for up to $96 \mathrm{~h}$ with minimal deterioration of quality as long as the milk entering the tank has minimal bacterial contamination.

\section{ACKNOWLEDGMENTS}

Sincere gratitude is due to Marta Alisia Bagalini and Jimmy Flynn (Animal and Grassland Research and Innovation Centre, Teagasc, Moorepark, Fermoy) and Conor Doyle (Teagasc Food Research Centre, Moorepark, Fermoy). This work was supported by The Dairy Levy Research Trust (Dublin, Ireland). Aine O'Connell was in receipt of a Teagasc Walsh Fellowship.

\section{REFERENCES}

Aureli, P., and G. Franciosa. 2002. Clostridium spp. Pages 456-463 in Encyclopedia of Dairy Sciences. H. Roginski, J. W. Fuquay, and P. F. Fox, ed. Elsevier, London, UK..

Banks, J. M., M. W. Griffiths, J. D. Phillips, and D. D. Muir. 1988. A comparison of the effects of storage of raw milk at $2^{\circ} \mathrm{C}$ and $6^{\circ} \mathrm{C}$ on the yield and quality of Cheddar cheese. Food Microbiol. 5:9-16.

Barbano, D. M., Y. Ma, and M. V. Santos. 2006. Influence of raw milk quality on fluid milk shelf life. J. Dairy Sci. 89(E-Suppl.):E15-E19.

Celestino, E. L. M., H. Iyer, and H. Roginski. 1996. The effects of refrigerated storage on the quality of raw milk. Aust. J. Dairy Technol. 51:59-63.

Chambers, J. V. 2002. The microbiology of raw milk. Pages 39-90 in Dairy Microbiology Handbook. 3rd ed. R. K. Robinson, ed. John Wiley \& Sons Inc., Publication, New York, NY.

DAFM. 2010. Food Harvest 2020. A vision for Irish agri-food and fisheries. Accessed Jun. 21, 2013. http://www.agriculture.gov.ie/ media/migration/agri-foodindustry/foodharvest2020/2020FoodH arvestEng240810.pdf.

European Economic Community. 1992. Council Directive 92/46/EEC. Commission document 39L0046. June 1992. EEC, Brussels, Belgium.

Forsbäck, L., H. Lindmark-Månsson, K. Svennersten-Sjaunja, L. Bach Larsen, and A. Andrén. 2011. Effect of storage and separation of milk at udder quarter level on milk composition, proteolysis, and coagulation properties in relation to somatic cell count. J. Dairy Sci. 94:5341-5349.

Frank, J. F., and A. E. Yousef. 2004. Test for groups of microorganisms. Pages 227-248 in Standard Methods for the Examination of Dairy Products. 17th ed. H. M. Wehr and J. F. Frank, ed. Am. Public Health Assoc., Washington, DC.

Fromm, H. I., and K. J. Boor. 2004. Characterization of pasteurized fluid milk shelf-life attributes. J. Food Sci. 69:207-214.

Graham, T. 2004. Sampling dairy and related products. Pages 63-91 in Standard Methods for the Examination of Dairy Products. 17th ed. H. M. Wehr and J. F. Frank, ed. Am. Public Health Assoc., Washington, DC.

Griffiths, M. W., J. D. Phillips, and D. D. Muir. 1987. Effect of lowtemperature storage on the bacteriological quality of raw milk. Food Microbiol. 4:285-291.
Griffiths, M. W., J. D. Phillips, I. G. West, A. W. M. Sweetsur, and D. D. Muir. 1988. The quality of skim-milk powder produced from raw milk stored at $2^{\circ} \mathrm{C}$. Food Microbiol. 5:89-96.

Guinot-Thomas, P., M. Al Ammoury, and F. Laurent. 1995. Effects of storage conditions on the composition of raw milk. Int. Dairy J. 5:211-223.

ISO. 2003. ISO 15213:2003. Microbiology of food and animal feeding stuffs - Horizontal method for the enumeration of sulphite-reducing bacteria growing under anaerobic conditions. International Organization for Standardization (ISO), Geneva, Switzerland.

Kelly, P. T., K. O'Sullivan, D. P. Berry, S. J. More, W. J. Meaney, E. J. O'Callaghan, and B. O'Brien. 2009. Herd management factors associated with bulk tank total bacterial count in Irish dairy herds during 2006/07. Ir. Vet. J. 62:36-42.

Laird, D. T., S. A. Gambrel-Lenarz, F. M. Scher, T. E. Graham, and R. Reddy. 2004. Microbiological count methods. Pages 153-186 in Standard Methods for the Examination of Dairy Products. 17th ed. H. M. Wehr and J. F. Frank, ed. Am. Public Health Assoc., Washington, DC.

Magnusson, M., A. Christiansson, and B. Svensson. 2007. Bacillus cereus spores during housing of dairy cows: Factors affecting contamination of raw milk. J. Dairy Sci. 90:2745-2754.

Malcarne, M., A. Summer, P. Franceschi, P. Formaggioni, M. Pecorari, G. Panari, P. Vecchia, S. Sandri, E. Fossa, C. Scotti, and P. Mariani. 2013. Effects of storage conditions on physico-chemical characteristics, salt equilibria, processing properties and microbial development of raw milk. Int. Dairy J. 29:36-41.

Moatsou, G., and E. Moschopoulou. 2014. Microbiology of raw milk. Pages 1-38 in Dairy Microbiology and Biochemistry. B. H. Ozer and G. Akdamir-Evrendilek, ed. CRC Press, Boca Raton, FL.

Muir, D. D. 1996. The shelf-life of dairy products: 1. Factors influencing raw milk and fresh products. Int. J. Dairy Technol. 49:24-32.

Muir, D. D., M. E. Kelly, and J. D. Phillips. 1978. The effect of storage temperature on bacterial growth and lipolysis in raw milk. Int. J. Dairy Technol. 31:203-208.

O'Brien, B., T. Beresford, and F. McCoy. 2009. Importance of producing high quality milk. T-research 4:46-47 Accessed Oct. 6, 2015. http://www.teagasc.ie/publications/2009/15/15_tresearch200905. pdf.

O'Connell, A., P. L. Ruegg, and D. Gleeson. 2013. Farm management factors associated with the Bacillus cereus count in bulk tank milk. Ir. J. Agric. Food Res. 52:229-241.

Rasolofo, E. A., D. St-Gelais, G. LaPointe, and D. Roy. 2010. Molecular analysis of bacterial population structure and dynamics during cold storage of untreated and treated milk. Int. J. Food Microbiol. 138:108-118.

SAS Institute. 2011. SAS 9.3 Output Delivery System: User's Guide. SAS Institute Inc., Cary, NC.

Tallent, S. M., K. M. Kotewicz, E. A. Strain, and R. W. Bennett. 2012. Efficient isolation identification of Bacillus cereus group. J. AOAC Int. 95:446-451.

Upton, J., J. Humphreys, P. W. G. Groot Koerkamp, P. French, P. Dillon, and I. J. M. De Boer. 2013. Energy demand on dairy farms in Ireland. J. Dairy Sci. 96:6489-6498.

Vissers, M. M., F. Driehuis, M. Te Giffel, P. De Jong, and J. Lankveld. 2007. Minimizing the level of butyric acid bacteria spores in farm tank milk. J. Dairy Sci. 90:3278-3285.

Wiking, L., M. B. Frøst, L. B. Larsen, and J. H. Nielsen. 2002. Effects of storage conditions on lipolysis, proteolysis and sensory attributes in high quality raw milk. Milchwissenschaft 57:190-194. 